\title{
Quality Evaluation of the Non-Variceal Upper Gastrointestinal Bleeding Guidelines/Consensuses via AGREE II Tools
}

\author{
Yu Wang1, Jun Guo2, Youyi Rao1, Gui Rong Xiao4 and Xinhua Zhao ${ }^{3}$ \\ IDepartment of Pharmacy / Pediatrics ${ }^{2}$ / Gastroenterology33, Mian Yang Center Hospital, Mian Yang 621000, China \\ ${ }^{4}$ Department of Pharmacy, West China Hospital of Sichuan University, Chengdu, 621000, China
}

\begin{abstract}
Non-variceal upper gastrointestinal bleeding (NUGIB) is a common disease in clinical practice; and many related guidelines/consensuses have been published. The authors assessed the methodological quality of the NUGIB guidelines/ consensuses published in English, in order to uncover which guidelines/consensuses are of better quality in methodology and the deficiency in the area. Appraisal of guidelines for research \& evaluation instrument tools were adopted to assess the quality of the guidelines/consensuses. Each guideline/consensus was assessed independently by three researchers. Intra-class correlation (ICC) among researchers was retrieved to reflect reliability. Eight guidelines/consensuses regarding the management of NUGIB published in English were obtained. The ICCs among the evaluators were all above 0.75, indicating satisfactory reliability. Quality evaluation of the obtained guidelines via the AGREE II tools showed that the overall quality of the included guidelines/consensuses was moderate in all domains. A few guidelines/consensuses were better developed in scientific and methodological aspects than the others. The grades of recommendations with the guidelines/consensuses, according to a brief and preliminary scheme, were of practical value. Moreover, the recommendations regarding the pharmacological treatments in the guidelines/consensuses above, are various according to the study. Overall, the quality of some NUGIB guidelines/consensuses were generally acceptable and applicable, those yet are with minor deficiencies. The others may be improved according to the AGREE II items, likely by evaluating the quality of the guidelines/consensuses when the guidelines/consensuses are updated.
\end{abstract}

Key Words: Non-variceal upper gastrointestinal bleeding, Quality evaluation, AGREE II tools.

How to cite this article: Wang Y, Guo J, Rao Y, Xiao GR, Zhao X. Quality evaluation of the non-variceal upper gastrointestinal beeding guidelines/consensuses via AGREE II tools. J Coll Physicians Surg Pak 2019; 29(10):977-85.

\section{INTRODUCTION}

Non-variceal upper gastrointestinal bleeding (NUGIB) refers to gastrointestinal hemorrhage occurring above the Treitz ligament without the comorbidities of esophageal, gastric or duodenal varices. ${ }^{1}$ In recent years, several guidelines/consensuses for the diagnosis and treatment of NUGIB have been published. As a common disease in clinical practice, these guidelines/ consensuses are very important to improve the clinical management of patients with NUGIB.2,3 However, in general, the guidelines/consensuses should be formulated by reference to some frameworks to confirm the good quality that would be more rigorous and scientific. The more rigorous and scientific the guidelines/ consensuses are, the greater the potential effect of clinical assistance would be. But the guidelines/ consensuses are formulated and compiled by the members from the different professions, institutions and nations which may be different knowledge structure,

Correspondence to: Xinhua Zhao, Department of Gastroenterology, Mian Yang Center Hospital, Mian Yang 621000, China

E-mail:lcyx2242469@126.com

Received: February 07, 2019; Revised: April 01, 2019;

Accepted: May 23, 2019 medical conditions and socio-economic development. There may be differences of the quality among these guidelines/consensuses. Therefore, a methodological quality evaluation for the published guidelines/consensuses is needed to identify the good quality guidelines/ consensuses and point out the limitations, and to provide the comments for improvement and optimization of the clinical management of the patients.

The Appraisal of Guidelines for Research \& Evaluation Instrument (AGREE tool) has been published by AGREE cooperative group and was updated in 2013 (AGREE II). This authorised tool has been recommended as a prevalent tool for evaluating clinical guidelines, 4,5 and can also be used to evaluate the quality of the consensuses and the position statement. ${ }^{6}$ Unfortunately, the quality of the guidelines/consensuses regarding the management of NUGIB, to the best of our knowledge, has been rarely evaluated. Some of them may not be of good quality, with less scientific significance and rigorous. Therefore, to optimise the clinical management of NUGIB, this study assessed the methodological quality of the guidelines/consensuses for the management of NUGIB integrally via AGREE II tool. The results of our study may be of clinical importance for the future development of related clinical guidelines. 


\section{METHODOLOGY}

In this study, NUGIB guidelines/consensuses written in English, which were published within 10 years, were included. The latest version of the guidelines/ consensuses that was developed by the same institution was adopted. The guidelines/consensuses were excluded if the documents merely related to the bleeding of a single pathology, such as the gastritis, peptic ulcer, gastric cancer, etc. Moreover, redundant publications of the same guidelines/consensuses in different journals were also excluded. The guidelines/consensuses for the diagnosis and treatment of non-varicose upper gastrointestinal bleeding were searched from January 2008 to April 2018 in PubMed, the Cochrane Library, Science Direct, National Guideline Clearing House (www.guideline.gov), National Institute for Health and Care Excellence (www.nice.org.uk.com), Australian Clinical Practice Guidelines (www.clinical guidelines.gov.aur.r.), and Guidelines International Network (www.g-i-n.net). Articles were included if their title included the following terms: nonvariceal or nonvariceal, and guideline, guidelines, guidance, consensus, statement, or position.

Data regarding the number of references and editors, the publication institutions, the country or area, the time of publication, the method of evidence evaluation, and the drug treatment recommendations for all guidelines/ consensuses were extracted.

Three assessors independently participated in the quality assessment procession of the guidelines/ consensuses. To ensure that there is an equal standard among the different assessors, all researchers had been trained for the AGREE II tool. The assessors independently responded to 23 questions of six domains by giving 1 for 'strongly disagree' to 7 for 'strongly agree'. Each domain score was calculated as the following: (the actual score - the lowest possible score)/(the highest possible score - the lowest possible score) $\times 100 \%$. Then the three scores by different assessors are averaging operation. The higher the score, the more normative the domain. ${ }^{7}$

To our disappointment, there was no break point of scores recommended by the AGREE II tool to distinguish between high and poor quality guidelines/ consensuses. As reported in previous studies, a score $>60 \%$ is frequently defined as high quality. ${ }^{8,9}$ However, the documents of medium quality failed to be distinguished from the low, and there is no sufficient influence on clinical practice. A new standard has been proposed in some studies, 10,11 through which the guidelines/consensuses could be categorised into three levels according to the scores of AGREE II: Grade C (not recommended): 3 domains with a score $<30 \%$. The guidelines/consensuses are not recommended; Grade B (recommended after revision): 3 domains of score $30 \%$, but at least one domain of score $<60 \%$. The guide- lines/consensuses could be recommended after modification. Grade A (recommended): 6 domains with a score $60 \%$. This could be used in this study.

The intra-class correlation coefficient (ICC) was introduced by Fisher in 1921 to measure the reliability of measurements or ratings. It is designed to assess the consistency or conformity between two or more quantitative measurements. 12 ICC was used to evaluate the consistency of assessment, ranging from 0 to 1 . The higher the value, the better the consistency of the assessment by different researchers. Specifically, the consistency is considered sufficient when the ICC $\geq 0.75$ and is deemed poor when the ICC $\leq 0.4$. For ICC ranging between 0.4 and 0.75 , the consistency is mediocre. Furthermore, to identify whether the intra-class correlation coefficient is statistically significant.The ICC has been tested by the Analysis of Variance, the above standards are available only when $p<0.05 .13,14$

The descriptive statistics of performance of guidelines/ consensuses in six AGREE II domains were got in order to describe the distribution of the score in each domain. Specifically, the score of different guidelines/consensuses in each domain were used to obtain the mean value, median value, standard deviation and so forth. Those could partly illustrate the distribution characteristics and the dispersion degree of quality of guidelines/consensuses in each domain.

All analyses above were performed with Statistical Product and Service Solutions (SPSS) version 23.0. SPSS is a widely used programme for statistical analysis in science. The functions of SPSS include data management, statistical analysis, chart analysis and so forth. The statistical analysis process includes but not limited to descriptive statistics, hypothesis test, and correlation analysis.

\section{RESULTS}

Eight documents were obtained during the literature search, including four guidelines, three consensuses and one statement (Figure 1). These guidelines/ consensuses were published from 2008 to 2018 in 5-46 pages having 17-317 references and 7-34 authors in total. The majority are updated versions of the previous editions, except for one from Poland. Three guidelines/consensuses were published by the Society of Gastrointestinal Endoscopy and one guideline/consensus was issued by a medical university. The characteristics of the included guidelines are presented in Table I.

The ICCs of the guidelines / consensuses among the three researchers were all $\geq 0.75(p<0.05)$, which are presented in Table II, and indicated that the consistencies for the quality evaluation within different researchers are satisfactory.

The scores of each domain and the recommendation grade of all the guidelines/consensuses were recorded by the AGREE II tool. The mean score was $<60 \%$. The 
recommendation grades of the guidelines/consensuses are of Grade B and C rather than Grade A. The European, International and Asia-Pacific guidelines/consensuses were higher than the other scores in most domains. The scores of 4 domains were above $60 \%$ for the European guidelines/consensuses, whereas none were
$<30 \%$ with the integral best quality. The scores of Chinese, Indonesian and Polish guidelines/consensuses were all only 1 domain above $30 \%$ but $<60 \%$, the other domains were $<30 \%$. (Tables III and IV, Figure 2).

All of the guidelines/consensuses stated that Proton Pump Inhibitors (PPIs) are the optimal agent for NUGIB

Table I: Characteristics of the retrieved clinical guidelines/consensuses.

\begin{tabular}{|c|c|c|c|c|c|c|c|}
\hline Names of guidelines and consensus & Type & Institutions & $\begin{array}{l}\text { Authors } \\
\text { number }\end{array}$ & $\begin{array}{l}\text { Updated } \\
\text { version }\end{array}$ & $\begin{array}{l}\text { No. of } \\
\text { references }\end{array}$ & $\begin{array}{c}\text { Year of } \\
\text { publication }\end{array}$ & $\begin{array}{l}\text { Evidence } \\
\text { evaluation } \\
\text { tool }\end{array}$ \\
\hline $\begin{array}{l}\text { Diagnosis and management of nonvariceal upper } \\
\text { gastrointestinal hemorrhage: European Society of } \\
\text { Gastrointestinal Endoscopy (ESGE) Guideline }{ }^{15}\end{array}$ & Guidelines & $\begin{array}{l}\text { European Society of } \\
\text { Gastrointestinal } \\
\text { Endoscopy }\end{array}$ & 24 & yes & 317 & 2015 & Grade \\
\hline $\begin{array}{l}\text { International Consensus Recommendations on the } \\
\text { Management of Patients With Nonvariceal Upper } \\
\text { Gastrointestinal Bleeding } 16\end{array}$ & Consensus & $\begin{array}{c}\text { International } \\
\text { Consensus Upper } \\
\text { Gastrointestinal } \\
\text { Bleeding Conference } \\
\text { Group }\end{array}$ & 7 & yes & 225 & 2010 & Grade \\
\hline $\begin{array}{l}\text { Asia-Pacific Working Group consensus on non- } \\
\text { variceal upper gastrointestinal bleeding } 2\end{array}$ & Consensus & $\begin{array}{l}\text { Asia-Pacific Working } \\
\text { Group of Upper } \\
\text { Gastrointestinal } \\
\text { Bleeding }\end{array}$ & 18 & yes & 114 & 2018 & $\begin{array}{l}\text { Not } \\
\text { available }\end{array}$ \\
\hline $\begin{array}{l}\text { Guidelines for the diagnosis and treatment of acute } \\
\text { non-variceal upper gastrointestinal bleeding }{ }^{17}\end{array}$ & Guidelines & $\begin{array}{l}\text { Chinese Society of } \\
\text { Digestive Endoscopy }\end{array}$ & 34 & yes & 25 & 2015 & $\begin{array}{l}\text { Not } \\
\text { available }\end{array}$ \\
\hline $\begin{array}{l}\text { National Consensus on Management of Non-Variceal } \\
\text { Upper Gastrointestinal Tract Bleeding in Indonesia18 }\end{array}$ & Consensus & $\begin{array}{l}\text { The Indonesian } \\
\text { Society of } \\
\text { Gastroenterology }\end{array}$ & $\begin{array}{l}\text { Not } \\
\text { available }\end{array}$ & yes & 17 & 2014 & $\begin{array}{l}\text { Not } \\
\text { available }\end{array}$ \\
\hline $\begin{array}{l}\text { Guidelines for endoscopic management of non- } \\
\text { variceal upper gastrointestinal bleeding }{ }^{19}\end{array}$ & Guidelines & $\begin{array}{l}\text { Japan } \\
\text { Gastroenterological } \\
\text { Endoscopy Society }\end{array}$ & 10 & yes & 227 & 2016 & Grade \\
\hline $\begin{array}{l}\text { Non-variceal upper gastrointestinal bleeding } \\
\text { guidelines } \\
\text { on management } 20\end{array}$ & Guidelines & $\begin{array}{l}\text { Department of } \\
\text { Gastroenterology } \\
\text { Medical University of } \\
\text { Lublin }\end{array}$ & 6 & no & 80 & 2008 & $\begin{array}{l}\text { Not } \\
\text { available }\end{array}$ \\
\hline $\begin{array}{l}\text { Management of non-variceal upper gastrointestinal } \\
\text { bleeding } 21\end{array}$ & $\begin{array}{l}\text { Position } \\
\text { statement }\end{array}$ & $\begin{array}{l}\text { The Catalan Society } \\
\text { of Gastroenterology }\end{array}$ & 17 & yes & 108 & 2017 & Grade \\
\hline
\end{tabular}

Table II: The consistency assessment of the guidelines / consensuses evaluation by different researchers.

\begin{tabular}{|c|c|c|c|c|}
\hline Names of guidelines and consensus & The intra-class correlation coefficient & 95\% confidence interval & $\mathrm{F}$ & $\mathrm{P}$ \\
\hline European15 & 0.93 & $0.87-0.97$ & 14.34 & 0.00 \\
\hline International16 & 0.94 & $0.88-0.97$ & 16.29 & 0.00 \\
\hline Asia-pacific² & 0.95 & $0.90-0.98$ & 21.02 & 0.00 \\
\hline Chinese $^{17}$ & 0.94 & $0.87-0.97$ & 16.33 & 0.00 \\
\hline Indonesian 18 & 0.95 & $0.89-0.98$ & 18.61 & 0.00 \\
\hline Japanese $^{19}$ & 0.92 & $0.83-0.96$ & 11.82 & 0.00 \\
\hline Polish20 & 0.90 & $0.80-0.95$ & 9.579 & 0.00 \\
\hline Spanish21 & 0.95 & $0.89-0.98$ & 18.881 & 0.00 \\
\hline
\end{tabular}

2 The ICC are available only when $p<0.05$.

Table III: The score and recommendation level of the guidelines / consensuses by AGREE II.

\begin{tabular}{|c|c|c|c|c|c|c|c|c|c|}
\hline $\begin{array}{l}\text { Names of guidelines/ } \\
\text { consensus }\end{array}$ & $\begin{array}{l}\text { Scope and } \\
\text { purpose }\end{array}$ & $\begin{array}{l}\text { Stakeholder } \\
\text { involvement }\end{array}$ & $\begin{array}{c}\text { Rigor of } \\
\text { development }\end{array}$ & $\begin{array}{c}\text { Clarity of } \\
\text { presentation }\end{array}$ & Applicability & $\begin{array}{c}\text { Editorial } \\
\text { Independence }\end{array}$ & $\begin{array}{c}\text { No. of score } \\
60 \%\end{array}$ & $\begin{array}{l}\text { No. of score } \\
<30 \%\end{array}$ & $\begin{array}{c}\text { Grades of } \\
\text { recommendations }\end{array}$ \\
\hline European & 61.11 & 33.33 & 61.81 & 74.07 & 34.72 & 72.22 & 4 & 0 & $B$ \\
\hline International & 51.85 & 44.44 & 52.08 & 77.78 & 33.33 & 36.11 & 1 & 0 & B \\
\hline Asia-pacific & 44.44 & 22.22 & 44.44 & 62.96 & 36.11 & 52.78 & 1 & 1 & B \\
\hline Chinese & 42.59 & 20.37 & 7.64 & 22.22 & 20.83 & 0.00 & 0 & 5 & C \\
\hline Indonesian & 53.70 & 12.96 & 5.56 & 12.96 & 19.44 & 0.00 & 0 & 5 & C \\
\hline Japanese & 18.52 & 14.81 & 42.36 & 27.78 & 13.89 & 52.78 & 0 & 4 & C \\
\hline Polish & 29.63 & 12.96 & 7.64 & 14.81 & 16.67 & 36.11 & 0 & 5 & C \\
\hline Spanish & 40.74 & 18.52 & 20.83 & 53.70 & 26.39 & 58.33 & 0 & 3 & $\mathrm{C}$ \\
\hline
\end{tabular}


Pubmed $n=13$, Science Direct $n=34$, Cochrane Library $n=10$ National Guideline

Clearinghouse $n=23$, National Institute for Health and Care Excellence $n=42$, Australian

Clinical Practice Guidelines $=0$, Guidelines International Network $=0$, total $n=122$

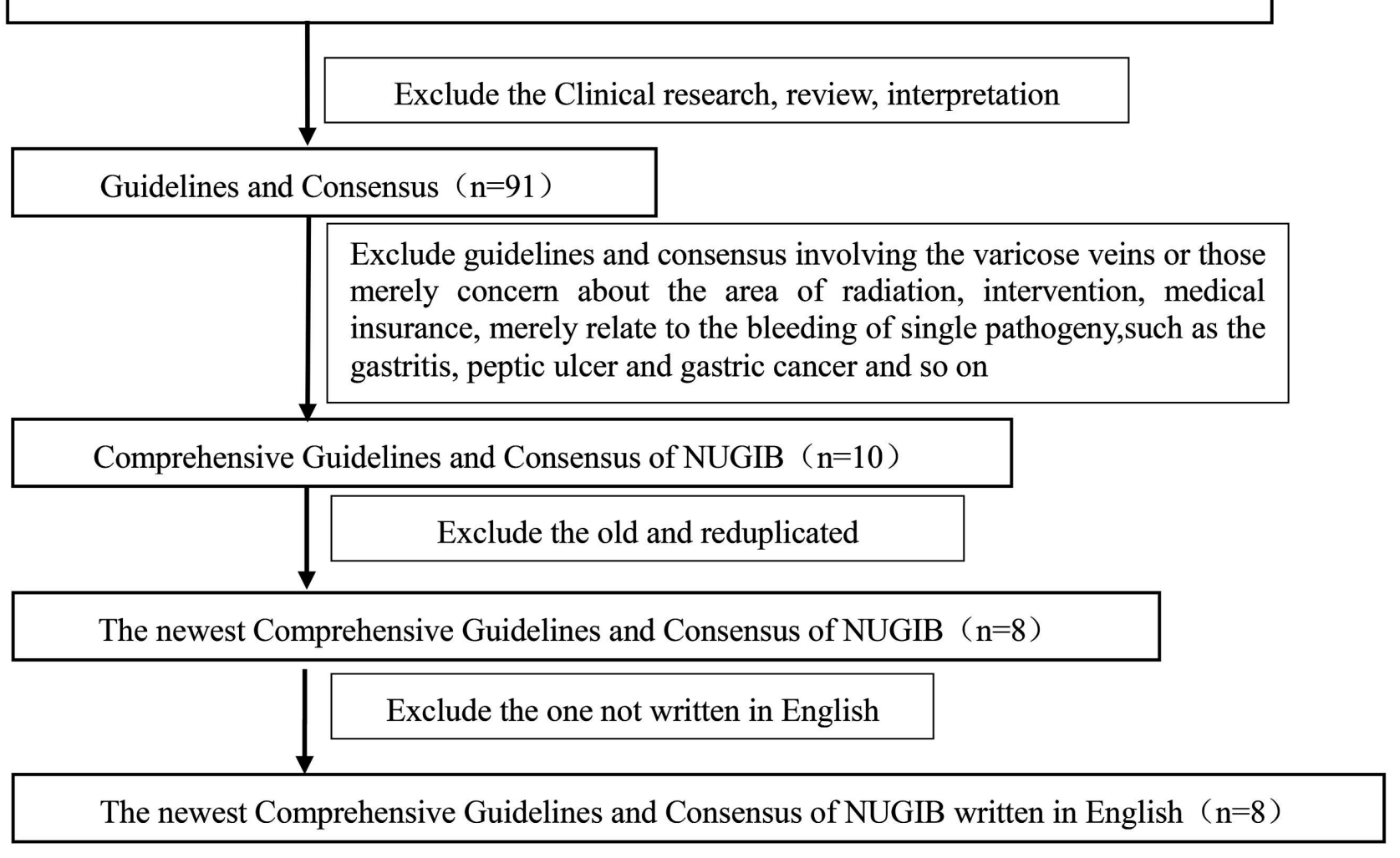

Figure 1: The process of the literature search.

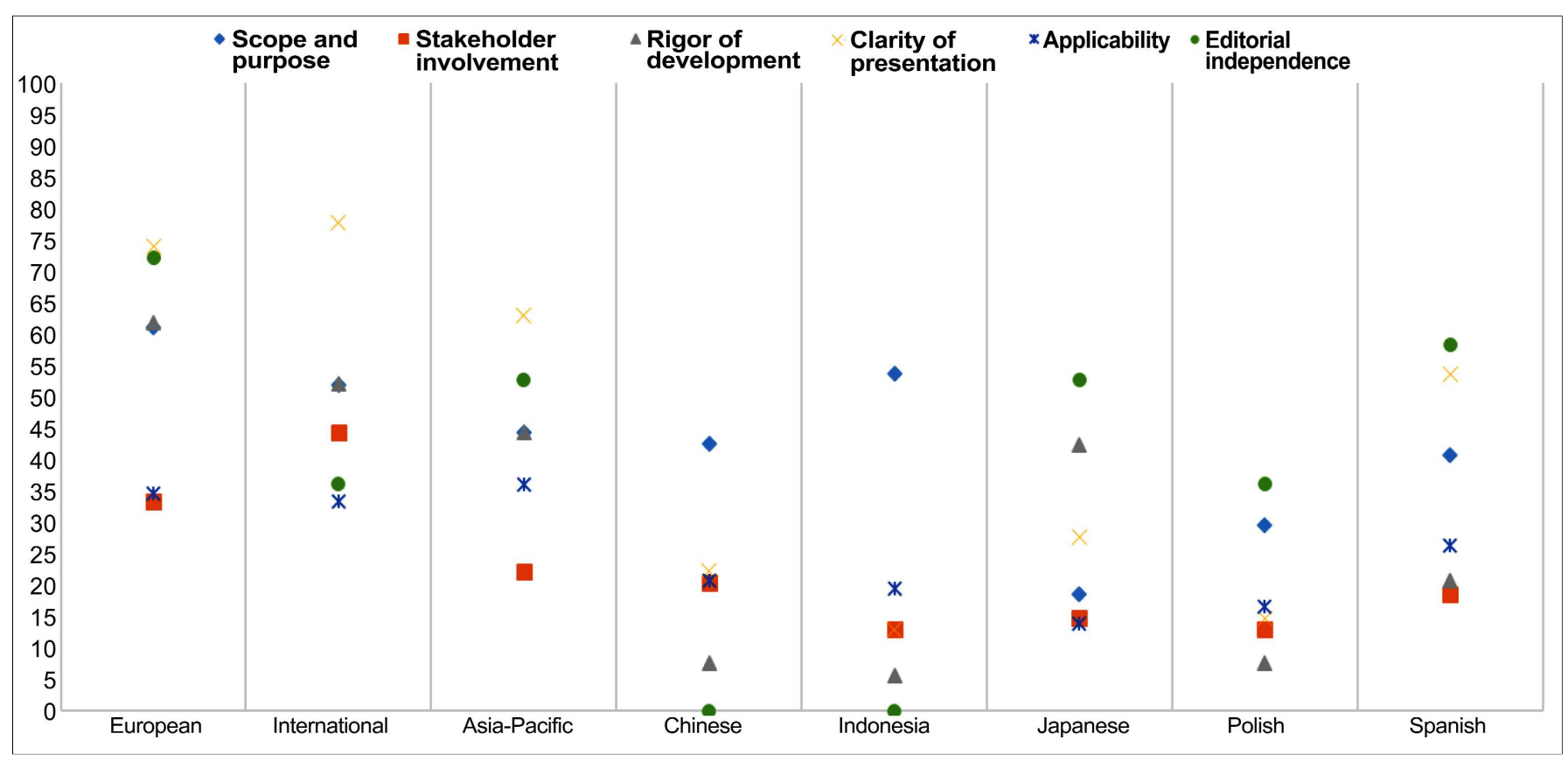

Figure 2: The score distributions of the guidelines / consensuses in 6 domains. 
Table IV: Descriptive statistics of performance of guidelines / consensuses in six AGREE II domains.

\begin{tabular}{|c|c|c|c|c|c|c|c|c|}
\hline AGREE II domain (\%) & Mean & Median & Standard deviation & Variance & Range & First quartile & Second quartile & Third quartile \\
\hline Scope and purpose & 42.82 & 43.52 & 13.66 & 186.56 & $18.52-61.11$ & 32.41 & 43.52 & 53.24 \\
\hline Stakeholder involvement & 22.45 & 19.45 & 11.09 & 122.89 & $12.96-44.44$ & 13.42 & 19.45 & 30.55 \\
\hline Rigor of development & 30.30 & 31.60 & 22.49 & 505.90 & $5.56-61.81$ & 7.64 & 31.60 & 50.17 \\
\hline Clarity of development & 43.29 & 40.74 & 26.85 & 721.11 & $12.96-77.78$ & 16.66 & 40.74 & 71.29 \\
\hline Applicability & 25.17 & 23.61 & 8.70 & 75.73 & $13.89-36.11$ & 17.36 & 23.61 & 34.37 \\
\hline Editorial independence & 38.54 & 44.45 & 26.50 & 702.00 & $0-72.22$ & 9.03 & 44.45 & 56.94 \\
\hline
\end{tabular}

Table V: The recommended pharmaceutical treatment in the guidelines / consensuses.

\begin{tabular}{|c|c|c|c|c|}
\hline $\begin{array}{l}\text { Names of guidelines/ } \\
\text { consensus }\end{array}$ & $\begin{array}{l}\text { Proton Pump Inhibitors (PPIs) } \\
\text { Prior to endoscopic therapy }\end{array}$ & Endoscopic therapy post & $\begin{array}{l}\mathrm{H}_{2} \text { receptor antagonists } \\
\left(\mathrm{H}_{2} \mathrm{RA}\right)\end{array}$ & Other hemostatics \\
\hline European 15 & $\begin{array}{l}\text { Intravenous PPIs, intravenous } \\
\text { bolus followed by continuous } \\
\text { infusion ( } 80 \mathrm{mg} \text { then } 8 \mathrm{mg} / \mathrm{hour} \text { ). }\end{array}$ & $\begin{array}{l}\text { PPIs are given via intravenous bolus followed by } \\
\text { continuous infusion ( } 80 \mathrm{mg} \text { then } 8 \mathrm{mg} / \text { hour) for } \\
72 \text { hours. } \\
\text { (R3: strong, E4: high) } \\
\text { PPIs are given via intravenous drip intermittently } \\
\text { (at least twice daily) for } 72 \text { hours can be } \\
\text { considered. (R: weak, E: moderate). }\end{array}$ & & $\begin{array}{l}\text { The admission of } \\
\text { tranexamic, } \\
\text { somatostatin, } \\
\text { octreotide are not } \\
\text { recommend (R: strong, } \\
\text { E: low). }\end{array}$ \\
\hline International16 & & $\begin{array}{l}\text { An intravenous bolus followed by continuous- } \\
\text { infusion PPIs therapy should be used. (Agree, } \\
94 \%, \mathrm{R} \text { : strong, E: high) } \\
\text { Adjunct to endoscopic treatment, high-dose oral } \\
\text { PPI can be used to prevent rebleeding. (Accept- } \\
\text { agreement: } 88.9 \%, \text { E: moderate) }\end{array}$ & $\begin{array}{l}\text { It is not recommended } \\
\text { in patients with acute } \\
\text { ulcer bleeding }\end{array}$ & $\begin{array}{l}\text { The use of } \\
\text { somatostatin, } \\
\text { octreotide are not } \\
\text { recommended. }\end{array}$ \\
\hline Chinese $^{17}$ & $\begin{array}{l}\text { PPIs should be employed as early } \\
\text { as possible }\end{array}$ & $\begin{array}{l}\text { It has been recommended that for high-risk } \\
\text { patients, large-dose intravenous PPIs should be } \\
\text { administered for } 72 \mathrm{~h} \text {. The treatment duration of } \\
\text { high-dose PPIs can be extended and then } \\
\text { switched to intravenous infusion of standard-dose } \\
\text { PPIs twice daily for } 3-5 \text { days and finally to oral } \\
\text { administration of standard-dose PPIs, until the } \\
\text { ulcer heals. For low-risk patients, treatments using } \\
\text { standard-dose PPIs, via intravenous infusion, are } \\
\text { practical and suitable. }\end{array}$ & $\begin{array}{l}\mathrm{H}_{2} \mathrm{RA} \text { can be } \\
\text { considered but the } \\
\text { effects of PPIs are } \\
\text { significantly superior } \\
\text { than those of H2RA. }\end{array}$ & $\begin{array}{l}\text { Hemostatic drugs are } \\
\text { not recommended as } \\
\text { firstline treatment } \\
\text { options. }\end{array}$ \\
\hline Indonesian ${ }^{18}$ & $\begin{array}{l}\text { When endoscopy will be delayed } \\
\text { and can not be performed, an } \\
\text { intravenous PPIs therapy is } \\
\text { recommended. }\end{array}$ & $\begin{array}{l}\text { Patients with active bleeding or non-bleeding } \\
\text { visible vessel and adheren clot can be treatment } \\
\text { with intravenous PPIs therapy bolus. } \\
\text { Patients with a flat pigmented spot or clean-base } \\
\text { can be treatment with oral PPIs therapy. }\end{array}$ & & \\
\hline Japanese $^{19}$ & & $\begin{array}{l}\text { PPIs should be given to patients to prevent } \\
\text { rebleeding after successful endoscopic } \\
\text { hemostasis. (E: IVa, R: moderate) }\end{array}$ & $\begin{array}{l}\mathrm{H}_{2} \mathrm{RA} \text { could be given } \\
\text { after successful } \\
\text { endoscopic } \\
\text { hemostasis }(\mathrm{E} \text { : IVa, }\end{array}$ & \\
\hline Polish20 & $\begin{array}{l}\text { In high risk patients, endoscopic } \\
\text { procedure should be conducted } \\
\text { just after hemodynamic } \\
\text { compensation and intravenous } \\
\text { administration of PPIs at a high } \\
\text { dose. }\end{array}$ & $\begin{array}{l}\text { In the high risk group, treatment with PPIs should } \\
\text { be continued intravenously through the next } 72 \\
\text { hours, and subsequently oral administration } \\
\text { should be applied. In patients with medium and } \\
\text { low risk for bleeding recurrences, it advises, } \\
\text { respectively, the intravenous and oral } \\
\text { administration of PPls at a dose of } 40 \text { mg every } \\
12 \text { hours. }\end{array}$ & $\begin{array}{l}\mathrm{R}: \text { moderate) } \\
\text { The routine use of } \\
\mathrm{H}_{2} \mathrm{RA} \text { is not } \\
\text { recommended. }\end{array}$ & $\begin{array}{l}\text { Somatostatin and } \\
\text { analogue are not } \\
\text { recommended for } \\
\text { routine application. }\end{array}$ \\
\hline Spanish21 & $\begin{array}{l}\text { Administering intravenous PPIs is } \\
\text { recommended. } \\
\text { (R: strong, E: moderate) }\end{array}$ & $\begin{array}{l}\text { The administration of a PPIs ( } 80 \mathrm{mg} \text { intravenous } \\
\text { bolus followed by a continuous } 8 \mathrm{mg} / \mathrm{h} \text { infusion) is } \\
\text { recommended in patients at a high } \\
\text { risk of rebleeding ( } R \text { : strong, } \mathrm{E} \text { : high). } \\
\text { High oral doses could be administered if the patient } \\
\text { is ready to begin an oral diet (R: weak, E: moderate) }\end{array}$ & & $\begin{array}{l}\text { Tranexamic acid, } \\
\text { somatostatin or } \\
\text { octreotide are not } \\
\text { recommended. } \\
\text { (R: strong, E: low) }\end{array}$ \\
\hline
\end{tabular}

management. PPIs administration after endoscopic therapy was recommended by nearly all guidelines/ consensuses. However, some documents did not mention applying PPIs before the endoscopic therapy. The $\mathrm{H}_{2}$ Receptor Antagonist (H2RA) was recommended as the substitution for PPIs in the Japanese and Chinese guidelines/consensuses. Currently, no other hemostatics have been recommended in all guidelines/ consensuses. The details are presented in Table V.

\section{DISCUSSION}

This systematic evaluation of eight published guidelines/ consensuses of NUGIB management via a generally accepted AGREE II tool found that the overall quality of the included guidelines/consensuses were moderate in all domains. However, a few guidelines/ consensuses were well developed regarding scientific and methodological aspects. Discussion of the recommendations for the pharmacological treatment in the study may reduce 
the controversies and provide measures to promote the use of medical treatments in clinical practice.

The AGREE II tool is required to make the theoretical and practical significance explicit before the guidelines/ consensuses editing. To avoid the inadequate use of the guidelines/consensuses, it is also required to show the benefit to the society and the specific target population. In this domain, the score of the guidelines/consensuses are higher than the others except the domain of clarity of development. It illustrates a measure of good quality in this area. However, the majority of guidelines/ consensuses did not illustrate it completely, especially the Japanese and Polish guidelines/consensuses. In contrast, the European guidelines is better than the others. To a certain extent, these guidelines clearly expressed the aim of the guidelines, and the health question(s) covered by the guidelines. But the minor flaws still exist. The population (patients, public, etc.) to whom the guidelines/consensuses is meant to apply is not specifically described (adults or children, whether are with the neopathy or not). And the potential health impact of the guidelines on society and populations of patients did not state clearly.

The editors' locations and fields of investigation are related to the quality of the guidelines/consensuses. In particular, the NUGIB documents required the joint efforts of the physicians, endoscope technicians, emergency physicians, clinical researchers, and statistics professionals from different countries. There are increasing cases of multidisciplinary consults in the treatment of NUGIB, especially in refractory cases. ${ }^{22,23}$ However, many guidelines/consensuses lack editor information. Accordingly, it is difficult to identify whether the participators were from the same profession or area that may lead to a bias in recommendations. In particular, there are no information in the domain for the Japanese, Chinese and Indonesian documents. Moreover, the patients' points are not noted in all guidelines/ consensuses above, though many methods can be used to consider them. ${ }^{24}$ Finally, no appropriate users were recommended in the above documents, which may lead to a reduced compliance of the patients and may compromise efficacy. In this domain, there are a lot of space to improve with all guidelines/ consensuses.

The reliability of the recommendations based on evidence are reflections of the rigor of the guideline development. Therefore, the rigor of guidelines/ consensuses formulation is the most important factor of the guidelines/consensuses. The evidence search and evaluation require comprehensiveness, objectivity and repeatability. The scores of the domains in Chinese, Indonesian and Polish guidelines/consensuses are quite low $(<10 \%)$, which lacks a search strategy and the evidence selection criteria. This suggests that there is no adequate scientific process during the development of the above guidelines. The other documents contained the evidence retrieval strategy, although this is not sufficiently rigorous. Moreover, the external experts review was not noted in all of the guidelines/ consensuses above, illustrating the shortage of peer supervision. Furthermore, some of them have lack of innovation plans, that means there are few latest research results could be contacted with.

The recommendations were made separately according to high- or low-risk patients with the diagnosis and treatment in nearly all of the guidelines/consensuses, as recommended by the standards of AGREE II. In general, the score of this domain are higher than the others, especially in International or European guidelines/ consensuses. However, the recommendations of some guidelines/consensuses were expressed with the evidence described, which may obscure the user.

The scores of all guidelines/consensuses in this domain were lower. Most of them lacked advice and tools on how the recommendations can be put into practice. The potential resource implications were also absent. The health equity was widely recognised as relevant to clinical/public health practice and policy. However, considerable populations were also associated with poor quality medical care. 25 Of note, dissemination of guidelines/consensuses plays an important role in the spread of new medical technologies and can promote the application of new medical treatments. If the document did not illustrate the potential resource implications and barriers, there may not be sufficient support for economy and policy. Moreover, the monitoring and/or auditing criteria in some guidelines/ consensuses were absent. For example: how should the patients be categorised as high or low risk? Was it evaluated by the endoscope or the amount of bleeding? The Chinese guidelines did not answer these questions clearly. Therefore, the scores are relatively lower. It means that would need more revision than the other domains.

The donation organisation may influence the recommendations through the support of guidelines/consensuses. It is necessary to explain conflicts of interest. Except for Chinese and Indonesian documents, most of the guidelines/consensuses clarified the conflicts of interest among the donation organisations and editors. Most guidelines/consensuses above are less affected by the conflicts of interest causing by competitive relationship and other institutions. This can partly assure the impartiality of the guidelines/consensuses.

The most effective treatment of NUGIB is endoscopic therapy, especially in high-risk patients. However, pharmacotherapy is also an important adjuvant measure that was mentioned by all guidelines/consensuses above. Although, PPIs are currently considered as first class treatment protocols in all the guidelines/ consensuses, there are still arguments on some issues. 
The previous studies demonstrated that the application of PPIs in combination with endoscopic therapy can reduce rebleeding and the proportions of NUGIB patients requiring surgery. ${ }^{26}$ Notably, the dosages of the PPIs are limited to the high amount. However, the high dosage of PPIs was vaguely defined as $80 \mathrm{mg}+8 \mathrm{mg} / \mathrm{hour}$ or above $200 \mathrm{mg} / 24$ hours for 72 hours. Therefore, nearly all of the earlier versions of the guidelines/ consensuses recommended treatment with a high dosage of PPIs with intravenous lasting 72 hours after endoscopic therapy, but none of them recommended the specific dosage due to differences in the references. Several guidelines/consensuses have noticed PPIs adoption before endoscopic therapy. Some studies indicated that PPIs should be employed as early as possible to reduce the needs of endoscopic intervention and shorten the length of stay. 27,28 However, the issue had not been proved completely because of the defects of the studies.29,30 Therefore, it remains under debate. However, it is sure that most guidelines/consensuses above recommended PPIs with high dosages as the first-line therapeutic agent of NUGIB.

The controversies are far beyond those. With the development of the studies, more information has been obtained regarding the effectiveness of oral and low dose agents. Kaviani et al. demonstrated that oral omeprazole (20 mg every 6 hours) can reduce rebleeding, shorten the average length of hospital stay and transfuse effectively. ${ }^{31}$ It may also work in Asian countries. ${ }^{32}$ The systematic review also demonstrated that there are no differences between the oral and intravenous groups in rebleeding or mortality due to surgical treatment. ${ }^{33}$ It may identify the effectiveness of the oral agent. However, a meta-analysis compared high-dose omeprazole and pantoprazole therapy $(80 \mathrm{mg}$ bolus plus $8 \mathrm{mg} /$ hour for 72 hours) with nonhigh-dose omeprazole and pantoprazole (20-160 mg daily). ${ }^{34}$ No significant differences between high-dose continuous infusion and nonhigh-dose intermittent PPIs therapy for rebleeding at 30 days and mortality were detected. As a result, recommendations based on the above studies were made in some guidelines/consensuses, especially in Asia, because the researchers considered that it would be more effective with PPIs in this area. ${ }^{33}$ At first, in the international consensus, lower intravenous doses or high-dose oral PPIs therapy were considered to be effective after endoscopic therapy (especially in Asia), although they were not recommended as the first-line treatment. Then, European guidelines and a Spanish statement stated that intermittent PPIs intravenous bolus dosing (at least twice daily) for 72 hours can be considered, while it was recommended at a weak level. Subsequently, the Asia-Pacific consensus explained that adjunct to endoscopic treatment, high-dose oral PPIs can be used to prevent rebleeding. Overall, an increasing number of professionals tend to use PPIs economically and conveniently with sufficient effectiveness.
Most guidelines/consensuses did not recommend $\mathrm{H}_{2} \mathrm{RA}$ as the first-line treatment because of the disadvantage of $\mathrm{H}_{2} \mathrm{RA}$. The occurrence of the tolerance phenomenon and interaction between $\mathrm{H}_{2} \mathrm{RA}$ and the other drugs constricted the use of $\mathrm{H}_{2}$ RA. 35,36 Moreover, a tolerance phenomenon could appear rapidly in some cases, which could not be eliminated or weakened by increasing the dosages of $\mathrm{H}_{2} R A$. Pharmacologically, $\mathrm{H}_{2} \mathrm{RA}$ such as cimetidine and ranitidine are inhibitors of cytochrome $\mathrm{P} 450$, which can interfere with other agents metabolised by the isozyme. In general, the safety and efficacy of $\mathrm{H}_{2} \mathrm{RA}$ for NUGIB are inferior to those of PPIs, were not recommended as the first line-drugs by most guidelines / consensuses.

Other neutralising hemostatics and protective drugs such as somatostatin, tranexamic acid, carbazochrome sodium sulfonate, hemocoagulase and vitamin $\mathrm{K}$ are not recommended by any guidelines/consensuses for routine application in treatment of NUGIB due to their indeterminate efficiency. $37-40$ Some agents such as hemocoagulase may consume fibrinogen, leading to the incidence of idiopathic hemostasis failure. ${ }^{41}$ Furthermore, multiple hemostatics admissions may increase adverse drug reactions. Notably, there are few occurrences of hemostatics abuse in reality.

This study assessed the quality of documents published in English only, which could not reflect the quality of relevant guidelines/consensuses in non-English speaking areas. Moreover, the AGREE II tool do not assesses the facticity of recommendations, but focus on the formation and quality of the guidelines/consensuses.

\section{CONCLUSION}

The quality of some NUGIB guidelines/consensuses are generally acceptable and applicable, those yet are with minor deficiencies. Some may be improved with the AGREE II items, especially Japanese, Indonesian, Spanish, Polish and Chinese guidelines/consensuses, likely by evaluating the quality of the guidelines/consensuses when the guidelines/consensuses are updated. Although the formulations of guidelines/consensuses are influenced by many factors, the quality of them is restricted by these factors identically. However, guideline assessment tools such as AGREE II should be encouraged to be applied in guideline/consensus development to improve their methodological quality, since the guidelines/consensuses with excellent quality are of more facility to be recognised and accepted.

\section{CONFLICT OF INTEREST:}

Authors declared no conflict of interest.

\section{AUTHORS' CONTRIBUTION:}

YW: Research design; literature search and collection; the quality of the guidelines/consensuses assessment; manuscript creation. 
JG: Research design; the quality of the guidelines/ consensuses assessment; data statistics.

YR: Research design; the rate of progress supervision; the consultant of pharmacy.

GRX: Data statistics; manuscript creation.

$X Z$ : The quality of the guidelines/consensuses assessment; literature search and collection; the consultant of gastroenterology.

\section{REFERENCES}

1. Wilcox CM, Alexander LN, Cotsonis G. A prospective characterization of upper gastrointestinal hemorrhage presenting with hematochezia. Am J Gastroenterol 1997; 92:231-5.

2. Sung JJ, Chiu PW, Chan FKL, Lau JY, Goh KL, Ho LH, et al. Asia-Pacific working group consensus on non-variceal upper gastrointestinal bleeding. Gut 2018; 67:1757-68.

3. Tolunay O, Tolunay I, Yildizdas RD, Çelik T, Çelik Ü. Appraisal of the "pediatric ARDS: Consensus recommendations from the pediatric acute lung injury consensus conference" with the AGREE II instrument. Turk J Med Sci 2018; 48:84-8.

4. Wang Y, Ye ZK, Li JF, Cui XL, Liu LH. Heparin-induced thrombocytopenia: A critical appraisal of clinical practice guidelines with the AGREE II instrument. Thromb Res 2018; 166:10-8.

5. Larenas-Linnemann DES, Antolín-Amérigo D, Parisi C, Nakonechna A, Luna-Pech JA, Wedi B, et al. National clinical practice guidelines for allergen immunotherapy: An international assessment applying AGREE-II. Allergy 2018; 73:664-72.

6. Werner RN, Marinovic B, Rosumeck S, Strohal R, Haering NS, Weberschock $\mathrm{T}$, et al. The quality of European dermatological guidelines: Critical appraisal of the quality of EDF guidelines using the AGREE II instrument. J Eur Acad Dermatol Venereol 2016; 30:395-403.

7. AGREE Scientific. Appraisal of guidelines for research \& evaluation II instrument. http://www.agreetrust.org/agree-ii/.

8. Holmer HK, Ogden LA, Burda BU, Norris SL. Quality of clinical practice guidelines for glycemic control in type 2 diabetes mellitus. PLoS One 2013; 8:e58625.

9. Wong T, Stang AS, Ganshorn H, Hartling L, Maconochie IK, Thomsen AM, et al. Cochrane in context: Combined and alternating paracetamol and ibuprofen therapy for febrile children. Evid Based Child Health 2014; 9:730-2.

10. SC Cui, HY Hou, YP Li, YQ Chen. Clinical practice guidelines on infertility: A systematic review. Chinese $J$ Evid Based Med 2013; 13:947-54

11. Li CC, Wang YQ, Li YP, Li XL. Critical appraisal of clinical practice guidelines for pancreatic cancer based on the global disease burden. J Evid Based Med 2015; 8:11-21.

12. Atenafu EG, Hamid JS, To T, Willan AR, Feldman BM, Beyene J, et al. Bias-corrected estimator for intraclass correlation coefficient in the balanced one-way random effects model. BMC Med Res Methodol 2012; 12:126.

13. Li WG, Li YN, Zhang XM, Zhou XJ. Evaluating nine clinical practice guidelines for Vitamin $D$ supplementation in children and adolescents with AGREE: Recommendations and controversies. Chinese J Evid Based Pedia 2012; 7:372-9.
14. Jokhi RP, Ghule VV, Brown BH, Anumba DO. Reproducibility and repeatability of measuring the electrical impedance of the pregnant human cervix-the effect of probe size and applied pressure. Biomed Eng Online 2009; 8:10.

15. Gralnek IM, Dumonceau JM, Kuipers EJ, Lanas A, Sanders DS, Kurien $\mathrm{M}$, et al. Diagnosis and management of nonvariceal upper gastrointestinal hemorrhage: European Society of Gastrointestinal Endoscopy (ESGE) Guideline. Endoscopy 2015; 47:a1-a46.

16. Barkun AN, Bardou M, Kuipers EJ, Sung J, Hunt RH, Martel M, et al. International consensus recommendations on the management of patients with nonvariceal upper gastrointestinal bleeding. Ann Intern Med 2010; 152:101-13.

17. Y Bai, ZS Li. Guidelines for the diagnosis and treatment of acute non-variceal upper gastrointestinal bleeding (2015, Nanchang, China). J Dig Dis 2016; 2:79-87.

18. Indonesian Society of Gastroenterology. National consensus on management of non-variceal upper gastrointestinal tract bleeding in Indonesia. Acta Med Indones 2014; 46:163-71.

19. Fujishiro M, Iguchi M, Kakushima N, Kato M, Sakata $Y$, Hoteya $S$, et al. Guidelines for endoscopic management of non-variceal upper gastrointestinal bleeding. Dig Endosc 2016; 28:363-78.

20. Celinski K, Cichozlach H, Madro A, Slomka M, KasztelanSzczerbinska B, Dworzanski T. Non-variceal upper gastrointestinal bleeding guidelines on management. J Physiol Pharmaco 2008; 21:215-29.

21. García-Iglesias P, Botargues JM, Feu Caballé F, Villanueva Sánchez C, Calvet Calvo X, Brullet Benedi E, et al. Management of non-variceal upper gastrointestinal bleeding: position statement of the Catalan Society of Gastroenterology. Gastroenterol Hepatol 2017; 40:363-74.

22. House $T$, Webb $P$, Baarson $C$. Massive hemorrhage from ectopic duodenal varices: Importance of a multidisciplinary approach. Case Rep Gastroenterol 2017; 11:36-41.

23. Lee KE, Shim KN, Tae CH, Ryu MS, Choi SY, Moon CM, et al. Multidisciplinary approach to refractory upper gastrointestinal bleeding: case series of angiographic embolization. J Korean Med Sci 2017; 32:1552-7.

24. Yang C, Zhang Z, Zhang L, Tian J, Yu D, Wang J, et al. Quality assessment of clinical practice guidelines on TIC disorders with AGREE II instrument. Psychiatry Res 2018; 259:385-91.

25. Welch VA, Akl EA, Guyatt G, Pottie K, Eslava-Schmalbach J, Ansari MT, et al. GRADE equity guidelines 1: Considering health equity in GRADE guidelines development: Introduction and rationale. J Clin Epidemiol 2017; 90:59-67.

26. Leontiadis GI, Sharma VK, Howden CW. Proton pump inhibitor treatment for acute peptic ulcer bleeding. Cochrane Database Syst Rev 2004; 3:CD002094.

27. Lau JY, Leung WK, Wu JC, Chan FK, Wong VW, Chiu PW, et al. Omeprazole before endoscopy in patients with gastrointestinal bleeding. N Engl J Med 2007; 356:1631-40.

28. Sreedharan A, Martin J, Leontiadis GI, Dorward S, Howden CW, Forman $\mathrm{D}$, et al. Proton pump inhibitor treatment initiated prior to endoscopic diagnosis in upper gastrointestinal bleeding. Cochrane Database Syst Rev 2010; 7:CD005415.

29. Biecker E. Diagnosis and therapy of non-variceal upper gastrointestinal bleeding. World J Gastrointest Pharmacol Ther 2015; 6:172-82. 
30. Elphick DA, Riley SA. Omeprazole before endoscopy in patients with gastrointestinal bleeding. N Engl J Med 2007; 357:303-4.

31. Kaviani MJ, Hashemi MR, Kazemifar AR, Roozitalab S, Mostaghni AA, Merat S, et al. Effect of oral omeprazole in reducing rebleeding in bleeding peptic ulcers: A prospective, double-blind, randomized, clinical trial. Aliment Pharmacol Ther 2003; 17:211-6.

32. Sung JJ, Suen BY, Wu JC, Lau JY, Ching JY, Lee VW, et al. Effects of intravenous and oral esomeprazole in the prevention of recurrent bleeding from peptic ulcers after endoscopic therapy. Am J Gastroenterol 2014; 109:1005-10.

33. Neumann I, Letelier LM, Rada G, Claro JC, Martin J, Howden CW, et al. Comparison of different regimens of proton pump inhibitors for acute peptic ulcer bleeding (Review). Cochrane Database Syst Rev 2013; 6:CD007999.

34. Wang $\mathrm{CH}, \mathrm{Ma} \mathrm{MH}$, Chou $\mathrm{HC}$, Yen ZS, Yang CW, Fang CC, et al. High-dose vs non-high-dose proton pump inhibitors after endoscopic treatment in patients with bleeding peptic ulcer: A systematic review and meta-analysis of randomized controlled trials. Arch Intern Med 2010; 170:751-8.

35. Mcrorie JW, Kirby JA, Miner PB. Histamine2-receptor anta- gonists: Rapid development of tachyphylaxis with repeat dosing. World J Gastrointest Pharmacol Ther 2014; 5:57-62.

36. Takahashi M, Katayama Y. Reversal of the tolerance phenomenon by the intermittent administration of a histamine H2-receptor antagonist. J Gastroenterol Hepatol 2010; 25:1493-7.

37. Bennett C, Klingenberg SL, Langholz E, Gluud LL. Tranexamic acid for upper gastrointestinal bleeding. Cochrane Database Syst Rev 2014; 11:CD006640.

38. Choi CW, Kang DH, Kim HW, DaeKim M, Park SB, Park KT. The effect of adjunct treatment of somatostatin in nonvariceal upper gastrointestinal bleeding. Gastrointest Endoscop 2010; 71:AB261.

39. Avgerinos A, Rotondano G. Current views and future aspects in the management of non-variceal upper gastrointestinal bleeding: Role of somatostatin-14. Res Clin Forums 2002; 24 : 21-30.

40. Redeen S. The trend of tranexamic use in upper gastrointestinal bleeding ulcers. Gastroenterology Res 2017; 10:159-65.

41. Zhang C, Liu Y, Liu G. Hypofibrinogenemia caused by hemocoagulase after endoscopic sinus surgery: A case report. J Clin Otorhinolaryngo Head Neck Sur 2016; 30:70.

.... ז.... 